\title{
Mainstreaming Restorative Justice in South Australia's Criminal Justice System: A Response to the Over-Representation of Indigenous Offenders
}

\author{
Alexandra Smith
}

\section{Abstract}

John Braithwaite, a leading advocate for restorative justice, stated that: There can be no justice in a world without connectedness and empathy; at the same time, social capital cannot flourish in a world without an infrastructure of security around human relationships that can only be guaranteed by institutions of justice. ${ }^{1}$

In recent years, the concept of restorative justice has attracted much attention from policy makers, legal practitioners and social justice advocates. This essay discusses the shortcomings of South Australia's current court system and its failure to adequately respond to the needs of Indigenous offenders, and considers the potential for the increased use of principles of restorative justice to provide beneficial outcomes in addressing those needs. The following is a consideration of how mainstream criminal sentencing can be reimagined to integrate restorative justice, and suggests that South Australia adopt legislation based on the Crimes (Restorative Justice) Act 2004 (ACT) in order to mandate restorative justice considerations as a compulsory part of the criminal sentencing process.

\section{Introduction}

Over the last three decades restorative justice has been established as a legitimate response to criminal behaviour. ${ }^{2}$ The benefits of restorative justice are increasingly being recognised internationally, with the United Nations encouraging states to develop guidelines and standards to govern the use

1 John Braithwaite 'Doing Justice Intelligently in Civil Society' (2006) 62 Journal of Social Issues 402.

2 Kelly Richards ‘Police-Referred Restorative Justice for Juveniles in Australia' (2010) 398 Trends \& Issues in Crime and Criminal Justice. 
of restorative justice programs. ${ }^{3}$ In line with Braithwaite's work, this essay argues that the principles of restorative justice can provide the foundations of strong institutions of justice built around the values of connectedness and empathy. In particular, given the High Court's recent recognition of the need to consider an offender's Indigenous background in Bugmy $v$ The Queen, ${ }^{4}$ this essay outlines the extent to which restorative justice may improve South Australia's criminal justice system to better serve the needs of Indigenous offenders and their communities.

The essay is divided into four parts. The first part considers the historic disadvantage faced by Indigenous peoples, and the inadequacy of South Australia's current criminal justice system in addressing the underlying causes of offending amongst this group. The second part proposes a solution to these issues in the form of legislation that creates a centralised restorative justice scheme to augment existing legislation. It is not the purpose of this essay to put forward a completed draft of legislation; rather, it outlines a legal framework largely modelled on the Crimes (Restorative Justice) Act 2004, which was recently introduced in the Australian Capital Territory. The third part considers the beneficial outcomes of such legislative change and the fourth explores the drawbacks of restorative justice and the political feasibility of the proposed legislative changes. The essay concludes that the SA Government should consider introducing legislation that will implement the principles of restorative justice in order to address the underlying issues that may cause criminal behaviour amongst all offenders; in particular Indigenous offenders.

\section{Definition}

The most commonly cited definition of restorative justice describes it as 'a process whereby all the parties with a stake in a particular offence come together to resolve collectively how to deal with the aftermath of the offence and its implications for the future ${ }^{5}{ }^{5}$ Restorative justice processes, however, do not necessarily involve face-to-face meetings between victim and offender. A broader approach to restorative justice recognises that the method encompasses a variety of practices at different stages in the criminal justice process, including conferences between victim and offender, diversion from court prosecution, redirection to rehabilitation programs - such as drug and alcohol therapy or anger management programs. This essay uses the definition of restorative justice outlined in the Explanatory Statement accompanying the ACT's Crimes

3 ECOSOC Resolution 2002/12, Basic Principles on the Use of Restorative Justice Programmes in Criminal Matters (United Nations Publication).

4 [2013] HCA 37.

5 T Marshall 'The Evolution of Restorative Justice in Britain' (1996) 4(4) European Journal of Criminal Policy and Research 37; T Marshall Restorative Justice: An Overview (London, Home Office, Research and Statistics Directorate, 1999). 
(Restorative Justice) Bill 2004, as a methodological tool to address underlying issues experienced by all those involved in the criminal justice system, including victims, offenders and their communities. ${ }^{6}$ Most relevant to this essay is the aim of restorative justice to have a constructive impact on the life of the offender. ${ }^{7}$ This essay focuses on how restorative justice processes may achieve this at the sentencing stage of the criminal justice process.

\section{Part One: Historic Disadvantage and the Inadequacy of Traditional Court Systems}

\section{Historic Disadvantage}

The imprisonment rate of Aboriginal and Torres Strait Islander peoples in Australia is considerably higher than the rest of the population in all Australian states and territories. South Australia has historically had the highest representation of Indigenous people in prison, ${ }^{8}$ with recent figures indicating that Indigenous men are 9.5 times more likely to be arrested than nonIndigenous men, and Indigenous women 16.3 times more likely to be arrested than their non-Indigenous counterparts. ${ }^{9}$ What is perhaps most striking is that this disproportionate representation of Indigenous people in the criminal justice system is unlikely to improve in the future, with young Indigenous people also being significantly over-represented in the criminal justice system. Young Aboriginal and Torres Strait Islander people account for approximately 1.2 per cent of the overall population of young people in Australia; ${ }^{10}$ however, they make up 21 per cent of young people on community justice orders, and 23 per cent of young people held in detention. ${ }^{11}$ Furthermore, despite the proven benefits of diversionary processes such as restorative justice conferencing, South Australia has recently been identified as a jurisdiction that is less likely to adopt these methods. ${ }^{12}$

6 Explanatory Statement, Crimes (Restorative Justice) Bill 2004 (ACT).

7 Elena Marchetti and Kathleen Daly 'Indigenous Sentencing Courts: Towards a Theoretical and Jurisprudential Model' (2007) 29 Sydney Law Review 424-25.

8 J Walker and S Salloom 'Australian Prisoners 1992' (Research Discussion Paper, Australian Institute of Criminology, 1993).

9 Troy Allard 'Understanding and Preventing Indigenous Offending' (Research Discussion Paper no. 9, 2010) 2-3.

10 Australian Bureau of Statistics 'Experimental Estimates of Aboriginal and Torres Strait Islander Australians' (Release no. 3238.0.55.001, June 2006).

11 Australian Institute of Health and Welfare 'Juvenile Justice in Australia 2008-09' (Juvenile Justice Series no. 7, 2011).

12 Troy Allard et al 'Police Diversion of Young Offenders and Indigenous Over-Representation' (2010) 390 Trends \& Issues in Crime and Criminal Justice 2; L Snowball 'Diversion of Indigenous Juvenile Offenders' (2008) 355 Trends \& Issues in Crime and Criminal Justice. 
In order to understand the significant over-representation of Indigenous people in Australia's criminal justice system, it is necessary to consider the ongoing systemic damage and chronic marginalisation of Indigenous communities. ${ }^{13}$ Australia's Indigenous communities have suffered systematic damage in the form of expropriation of their lands and the destruction of their culture and heritage and have endured governance that has effectively removed self-determination from their lives. Indigenous communities have been left emotionally traumatised and socially and economically excluded from mainstream society. ${ }^{14}$ Further, Australia's common law recognises that many Indigenous offenders come from backgrounds of social disadvantage characterised by abuse of alcohol and violence. ${ }^{15}$ It is well established that social and economic disadvantages engender antisocial and criminal behaviour. ${ }^{16}$ Additionally, systematic bias against Indigenous people within the criminal justice system and the impact of over-policing have contributed to this over-representation. ${ }^{17}$

The need for courts to consider the unique disadvantage suffered by Australia's Indigenous population is topical, given the recent High Court decision in the case of Bugmy $v$ The Queen. ${ }^{18}$ In this case, the High Court recognised the circumstances of severe deprivation of Aboriginal offenders and the disproportionate incarceration of Indigenous people. ${ }^{19}$ The Court explicitly acknowledged that the experience of growing up in a community affected by alcohol abuse and violence is a relevant consideration in sentencing, and may reduce an offender's moral culpability for criminal behaviour. ${ }^{20}$ This essay suggests that mainstreaming restorative justice processes during sentencing may provide an ideal mechanism by which to bring to light circumstances of severe disadvantage and uncover underlying causes of criminal offending. In doing so, restorative justice processes will direct courts to meet the sentencing requirements of Bugmy $v$ The Queen ${ }^{21}$ and will ensure that Indigenous offenders are sentenced in a manner informed by this cultural context.

\footnotetext{
13 B Steels et al 'When It's a Question of Social Health and Well-being, the Answer is not Prison' (2009) 7 Indigenous Law Bulletin 12.

14 Coraline Ober et al 'Debriefing in Different Cultural Frameworks: Responding to Acute Trauma in Australian Aboriginal Contexts' in Beverly Raphael and John Preston Wilson (eds) Psychological Debriefing: Theory, Practice and Evidence (Cambridge University Press: 2000).

15 Kennedy $v$ The Queen [2010] NSWCCA 260 at [53]; Fernando (1992) 76 A Crim R 58 at 62 (E); Bugmy v The Queen [2013] HCA 37 at [40].

16 Steels, above n $13,15$.

17 C Cunneen Conflict, Politics and Crime: Aboriginal Communities and the Police (Allen \& Unwin, 2001).

18 [2013] HCA 37.

19 Bugmy v The Queen [2013] HCA 37 at [31].

20 Bugmy v The Queen [2013] HCA 37 at [43], [44].

21 Bugmy v The Queen [2013] HCA 37.
} 


\section{Inadequacy of the Current Criminal Justice System}

A feature of the criminal justice system Australia-wide is the marked growth in prison populations over recent years. ${ }^{22}$ Such a growth in prison populations has not, however, been matched by a reduction in crime. There is little, if any, reliable evidence suggesting that increasing rates of incarceration reduce crime. ${ }^{23}$ Rather, studies have shown the reverse, exposing the counterproductive, harmful and brutalising nature of imprisonment. ${ }^{24}$ Academic commentators have observed that high rates of imprisonment may act as an indicator of the breakdown of a society's sense of values and community. ${ }^{25}$ This is reflective of the correlation between the high rates of imprisonment of Indigenous people and the historic social and economic exclusion suffered by this community.

It has been suggested that the current system of criminal justice not only fails to respond to these underlying issues and work towards repairing harm, but also that it may be an aggravating factor in itself. ${ }^{26}$ By nature, prisons are hierarchical organisations; even the conventional architecture of prisons embodies 'secrecy, invisibility, isolation and a lack of accountability' ${ }^{27}$ These factors are likely to encourage and normalise brutality and violence amongst inmates, fail to foster a sense of personal responsibility for behaviour, and do not prepare inmates to become law-abiding members of society upon release. ${ }^{28}$ Not only does this system fail to address the underlying causes of criminal behaviour, it may perpetuate the cycle of offending. ${ }^{29}$

The current prison system is incompatible with Indigenous culture, within which justice and accountability have their foundation on the notion of reintegrative shaming that requires the offender to face community members, family and respected elders that may play roles in the 'sentencing' and healing process. ${ }^{30}$ The one size fits all, 'process based conveyor belt' ${ }^{\prime 31}$ that is the current SA prison system is likely to heighten trauma felt by Indigenous communities, rather than recognise underlying historical social exclusion and rehabilitate individual offenders. A criminal justice system augmented by the principles

22 For example, the Australian Institute of Criminology notes that the average prison population grew by five per cent annually between the years 1984 and 2003 (Dot Goulding et al 'Restorative Prisons: Towards Radical Prison Reform' (2008) 20 Current Issues in Criminal Justice 231).

23 ibid.

24 See, for example, A Coyle The Prisons We Deserve (Harper Collins Publishers London, 1994); M Foucault Discipline and Punish (Penguin Group London, 1977); D Garland Punishment in Modern Society (Clarendon Press Oxford, 1990).

25 Coyle, above n 24, 6.

26 Debbie Laycock Restorative Justice: Offering Benefits to Victims, Offenders and Communities (2010) Centre

for Restorative Justice $<$ www.lawsocietysa.asn.au $>$.

27 Goulding, above n 22, 232.

28 ibid.

29 ibid.

30 ibid.

31 Steels, above n 13, 15. 
of restorative justice may, however, address these fundamental problems by recognising that emotional, social and health issues are intimately connected to criminal behaviour, and addressing these issues through rehabilitation.

\section{Part Two: The Legislative Context of Restorative Justice}

\section{Current Legislative Context}

This essay suggests that the issues mentioned above could be addressed through the introduction of restorative justice legislation to augment South Australia's existing criminal justice system in which there is only limited access to restorative justice. The Young Offenders Act 1993 (SA) provides access to 'family conferences', 32 which are similar to the concept of restorative justice conferences. These, however, deal only with offences committed by juveniles. Additionally, the Criminal Law (Sentencing) Act 1988 (SA) directs the court to consider the rehabilitation of the offender in sentencing deliberations ${ }^{33}$ and, in the case of Indigenous offenders, the court must be assisted by an Aboriginal justice officer' to provide advice on Aboriginal society and culture. ${ }^{34}$ It is also relevantly that a sentence of imprisonment may only be imposed where any other sentence would be inappropriate, having regard to the gravity or circumstances of the offence. ${ }^{35}$ Furthermore, in 1999 South Australia was the first state in Australia to convene an Indigenous Sentencing Court, in the form of the Nunga Court in Port Adelaide. These courts, which work to respect Indigenous culture and incorporate it into the criminal justice system, largely rely on conventional sentencing options because there is currently no legislative base for their existence. The Nunga Courts are bound, like any other sentencing court, by the Criminal Law (Sentencing) Act when determining sentences. Therefore, South Australia's current criminal law legislation applies principles of restorative justice only in a limited sense.

\section{Proposed Legislative Changes}

Whilst some theorists, such as Braithwaite, believe restorative justice could replace the conventional criminal justice system, ${ }^{36}$ others acknowledge that this

32 Young Offenders Act 1993 (SA), s10.

33 Criminal Law (Sentencing) Act 1988 (SA), s10(1) (m).

34 Criminal Law (Sentencing) Act 1988(SA), s9C(5) (a).

35 Criminal Law (Sentencing) Act 1988 (SA), s11(1) (iv).

36 John Braithwaite 'Restorative Justice and a Better Future' in E McLauglin et al (eds) Restorative Justice - Critical Issues (SAGE Publications, 2003) 56. 
may not be possible, and indeed should not be the ultimate aim. ${ }^{37}$ This essay does not recommend that the principles of restorative justice replace or usurp the current criminal justice system in South Australia; rather, that it augments current processes. In order to expand the application of restorative justice and ensure that it is applied consistently, it is recommended that a new piece of legislation be drafted with the intention of augmenting the Criminal Law (Sentencing) Act 1988 (SA). This essay suggests that this legislation be based on the Crimes (Restorative Justice) Act 2004 (ACT), which operates in conjunction with the Crimes (Sentencing) Act 2005 (ACT).

The scheme under the Crimes (Restorative Justice) Act 2004 (ACT) enables a range of criminal justice agencies and legal authorities to refer cases for restorative justice at every stage of the criminal justice process. The legislative scheme makes specific provision for restorative justice practices to apply to both juvenile and adult offenders, ${ }^{38}$ but it is being implemented in a twophase process. Currently, the scheme is in its 'first phase' and applies only to 'less serious offences' committed by juvenile offenders. Provisions applying to adult offenders will come into effect as part of the 'second phase'. ${ }^{39}$ This essay proposes that, given its potential benefits, the scheme be adopted in its entirety in South Australia.

Under this scheme, restorative justice takes the form of an initial conference between the offender and the victim or a victim's representative, ${ }^{40}$ whereby parties come to an agreement that includes measures intended to repair the harm caused by the offence' ${ }^{41}$ These agreements can take many forms, including apologies, community service, and programs directed to address the underlying causes of the offending behaviour. ${ }^{42}$ The scheme is discretionary, and allows referring agencies to judge the suitability of the matter for restorative justice based on the nature of each offence and the suitability of the offender to participate. ${ }^{43}$ These agencies can choose whether to refer a matter to restorative justice, whilst maintaining discretion to prosecute the matter within a mainstream court. ${ }^{44}$ To allow the continuation of the court process whilst pursuing a restorative justice solution, an offender may accept responsibility for an offence ${ }^{45}$ without

\footnotetext{
37 A Ashworth 'Is Restorative Justice the Way Forward for Criminal Justice?' in E McLauglin et al (eds) Restorative Justice - Critical Issues (SAGE Publications, 2003) 177.

38 Crimes (Restorative Justice) Act 2004 (ACT), s22.

39 Australian Law Reform Commission Family Violence: Improving Legal Frameworks: Consultation Paper (ALRC CPS 1, April 2010) 150.

40 Crimes (Restorative Justice) Act ACT 2004, s42.

41 Crimes (Restorative Justice) Act ACT 2004, s51(1).

42 Crimes (Restorative Justice) Act ACT 2004, s51(2)(a), (b), (d).

43 Explanatory Statement, above n 6, 3.

44 Crimes (Restorative Justice) Act ACT 2004, s7.

45 Crimes (Restorative Justice) Act ACT 2004, s19(1)(b)(ii).
} 
affecting his or her capacity to plead not guilty to the offence at a later court hearing. ${ }^{46}$ In this way, both restorative justice and mainstream court processes can run concurrently.

It is recommended that South Australia adopt legislation modelled on the Crimes (Restorative Justice) Act 2004 (ACT) to operate alongside the Criminal Law (Sentencing) Act 1988 (SA). This would ensure that the principles of restorative justice are considered at all stages of the criminal justice process. Such a scheme would expand the application of restorative justice in South Australia, implement flexible approaches to the use of restorative justice, and afford the court substantial discretion apply restorative justice. Such amendments would be in line with the current legislative requirement to 'act according to equity, good conscience and the substantial merits of the case without regard to technicalities and legal reforms. ${ }^{\prime 47}$

\section{Part Three: Potential Benefits of Restorative Justice}

\section{Outcomes}

Empirical evidence reveals that restorative justice is likely to have beneficial outcomes in the areas of recidivism, mental and physical health of offenders, as well as offender satisfaction. Foremost, restorative justice has been shown to reduce offender recidivism, ${ }^{48}$ with offenders who participate in restorative justice programs alongside a mainstream court process being 14 per cent less likely to reoffend. ${ }^{49}$ This is particularly evident in repeat offending for violent crime, which is 38 per cent lower in offenders who participate in restorative justice programs, compared to offenders who attend a mainstream court for the same type of offence. ${ }^{50}$ Recidivism, a term used interchangeably with reoffending or repeat offending, has been variously described as the 'reversion of an individual to criminal behaviour', ${ }^{51}$ the 'return of a prisoner to custody' ${ }^{52}$

\footnotetext{
46 Crimes (Restorative Justice) Act ACT 2004, s20(1).

47 Criminal Law (Sentencing) Act 1988 (SA), s6(c).

48 Jamie Beven et al 'Restoration or Renovation? Evaluating Restorative Justice Outcomes in Psychiatry' (2005) 12(1) Psychology and the Law 194.

49 Victorian Government Department of Justice Evaluating the Neighbourhood Justice Centre in Yarra 2007-2009 (2010) Neighbourhood Justice Centre <http://www.neighbourhoodjustice.vic.gov.au>.

50 J Hinchey 'Restorative Justice in the Australian Capital Territory from Apprehension to Parole' (2006)

72 Precedent 37.

51 Michael D Maltz Recidivism (Academic Press, Inc., 1984) 1.

52 Steering Committee, Australian Government Productivity Commission Report on Government Services (31 January 2006).
} 
and 'the reappearance of a juvenile in court' ${ }^{53}$ Recidivism is an issue in the SA criminal justice system, with 46.4 per cent of prison releases returning with a new correctional sanction within two years, which is slightly higher than the national average of 44.7 per cent. Overall, Australia currently sees an average of almost three arrests per criminal offender, and rates of recidivism are generally higher for Indigenous offenders. Of today's prison population, it is estimated that 77 per cent of adult Indigenous prisoners have been imprisoned at least once before. ${ }^{54}$ To consider the problem prospectively, 88 per cent of male Indigenous offenders aged between 18 and 21 years are expected to be rearrested within ten years of their first arrest, compared to 61 per cent of nonIndigenous prisoners. This disparity is similar in the older population, with 48 per cent of male Indigenous offenders aged 40 years or more expected to be rearrested within ten years of their first arrest, compared to 31 per cent of their non-Indigenous counterparts. ${ }^{55}$ It should be noted that the differences between Indigenous and non-Indigenous offending might be the result of differential rates of detection, rather than differences in propensity for reoffending. ${ }^{56}$ Given these statistics, however, it is clear that an outcome of reduced recidivism is likely to be particularly beneficial to Indigenous offenders.

Principles of restorative justice place a high importance on the health and rehabilitation of offenders. This is likely to have a beneficial impact on the mental and physical health of offenders and their ability to subsequently integrate into society. Offenders who make use of treatment programs are likely to confront underlying problems and develop law-abiding coping skills, as well as enhance interpersonal skills. In particular, drug and alcohol rehabilitation may have its greatest impact on Indigenous offending, as approximately half of Indigenous prisoners are reported to link their criminal offending to drug and alcohol use. ${ }^{57}$ Significantly, offenders who are redirected to residential rehabilitative treatment programs, rather than being sentenced to imprisonment, are also less likely to contract hepatitis C. ${ }^{58}$

Offenders experience a sense of justice and dignity when given the opportunity to be heard by a court. Research shows that court participants value highly involvement in a fair process, and they are more likely to adhere to court orders when they believe that they have been heard and respected when telling their stories. $^{59}$ Offenders who report greater satisfaction with court process are

\footnotetext{
53 Department of Human Services, Government of Victoria Recidivism among Victorian Juvenile Justice Clients 1997-2001 (2001).

54 ibid 60.

55 ibid 67.

56 ibid 92.

57 National Drug and Alcohol Committee An Economic Analysis for Aboriginal and Torres Strait Islander Offenders: Prison vs Residential Treatment (Australian National Council on Drugs, August 2012).

58 ibid.

59 Bruce Winick and David Wexler (eds) Judging in a Therapeutic Key (Carolina Press 2003) 129.
} 
more willing to comply with the outcome of criminal proceedings, even if the outcome is adverse to them. ${ }^{60}$ Those involved in the restorative justice programs implemented under the Crimes (Restorative Justice) Act 2004 (ACT) report overwhelmingly positive outcomes from their experiences with restorative justice. Recent figures indicate that 97 per cent of all users of restorative justice programs in the ACT, including victims and offenders, report satisfaction with the services received. ${ }^{61}$ Furthermore, 99 per cent of users felt they were treated with respect, and 98 per cent felt they were able to 'have their say' in the process. ${ }^{62}$ These high levels of satisfaction have translated into impressive rates of compliance, with 87 per cent of offenders complying with agreements made between victim and offender at restorative justice conferences. ${ }^{63}$ These agreements include community service commitments, arrangements to undergo counselling or enter into rehabilitative programs, and financial donations made by offenders to charitable organisations. ${ }^{64}$

\section{Restorative Justice and its Application to Indigenous Offenders}

Restorative justice may not only provide better outcomes for individual Indigenous offenders; it may contribute to addressing the wider problem of historically entrenched social disadvantage suffered by Indigenous communities. Restorative justice is said to be concerned with the restoration of relationships between humans, but also the 'restoration of social relationships of equality' ${ }^{65}$ This suggests that restorative justice not only has the potential to restore relationships between victim and offender, offender and the community, but also to work towards restoring the social relationships of inequality that characterise Australia's Indigenous community. The power of restorative justice to address wider problems of societal injustice is recognised by Braithwaite, who notes that empowering and respecting the offender through restorative justice mechanisms has the potential to restore damaged relationships within communities and prevent future injustices, ${ }^{66}$ rather than perpetuate the cycle of offending and further entrench social exclusion caused by the current criminal justice system. By recognising the inadequacy of the current criminal justice system and re-imagining our approach to criminal behaviour, progress may be made to remedy the over-representation of Indigenous people in our

60 Ibid.

61 ACT Justice and Community Safety Annual Report 2012-2013 (Australian Capital Territory 2013) 32, 118.

62 ibid 32.

63 ibid 30.

64 ibid 31.

65 J Llewellyn 'Dealing with the Legacy of Native Residential School Abuse in Canada: Litigation, ADR and Restorative Justice' (2002) 52 Toronto Law Journal 289-90.

66 J Braithwaite 'Setting Standards for Restorative Justice' (2002) 42 British Journal of Criminology 563, 569. 
criminal justice system. Doing so may identify underlying issues that cause criminal behaviour amongst Indigenous offenders. In this way, the criminal justice system has the potential to address and reverse the entrenched social disadvantage faced by the Indigenous community.

Evidence from international jurisdictions indicates that principles of restorative justice can be particularly relevant to addressing criminal behaviour within indigenous communities. The indigenous Maori population in New Zealand is disproportionately represented in the NZ criminal justice process. ${ }^{67}$ As with the Indigenous population of Australia, this is accounted for in part by the range of adverse social and environmental factors that put Maori people at a greater risk of repeating patterns of adult criminal activity. In 2006, the New Zealand Law Commission made recommendations to the NZ Government to expand restorative justice programs in the country, and increase court-referred restorative justice processes. ${ }^{68}$ The NZ experience of restorative justice has shown evidence of success, in particular with offences committed by individuals from indigenous Maori and Pacific Island cultures. It has been established that when restorative justice programs are utilised in sentencing, indigenous offenders are generally less frequently sentenced to imprisonment, imprisonment is for shorter sentences, and the rate of reoffending is reduced. ${ }^{69}$ This demonstrates the potential for restorative justice to address problems of historic disadvantage that are characteristic of both Maori and Aboriginal communities.

\section{Economic Benefits}

As well as offering potential benefits for individual offenders and the Indigenous community more broadly, restorative justice may present fiscal benefits for the criminal justice system. The current criminal justice system is expensive. In 2011, more than $\$ 3$ billion was spent on Australian prisons, with an estimated average cost per prisoner per day in $2012-13$ of $\$ 315$, or $\$ 114,832$ annually. Comparatively, the net financial benefit of residential rehabilitation programs compared to incarceration is $\$ 111,285$ over the lifetime of an offender. ${ }^{70}$ Such significant savings are likely to be politically and economically attractive features of restorative justice.

67 Policy, Strategy and Research Group Overrepresentation of Maori in the Criminal Justice System: An Explanatory Report (September 2007) Department of Corrections <http://www.corrections.govt.nz/_data/ assets/pdf_file/0004/285286/Over-representation-of-Maori-in-the-criminal-justice-system.pdf $>$.

68 New Zealand Law Commission Sentencing Guidelines and Parole Reforms Discussion Paper no. 94 (2006).

69 ibid.

70 National Indigenous Drug and Alcohol Committee, above n 52. 


\section{Part Four: Drawbacks of Restorative Justice}

\section{Discretion versus Continuity}

Whilst restorative justice offers a number of potential benefits, some features of the proposed scheme may be controversial. It is recognised that a cornerstone of our criminal justice system is consistency and predictability, and that judicial decisions should be made by reference to purely objective standards declared to the community in advance. ${ }^{71}$ Indeed, Braithwaite acknowledges that 'social capital cannot flourish in a world without an infrastructure of security ... that can only be guaranteed by institutions of justice'.$^{72}$ The criminal justice system in its current form tends towards uniform consistency in sentencing. The principles of restorative justice may, however, be at odds with these objectives. In order for restorative justice to be implemented effectively, it needs to be tailored to meet the unique needs of individual offenders. The outcome of a restorative justice conference, for example, cannot be known in advance because it is often the result of an exchange between victim and offender, ${ }^{73}$ and the court must be allowed significant discretion in imposing sentences consistent with any restorative justice conferencing agreement if it sees fit. It can be argued that this discretionary approach to sentencing may lead to 'unlike treatment of like cases'. ${ }^{74}$

Consistency is an abstract virtue, however, that should not outweigh the primary rationales for sentencing; rather, an effective justice system should provide justice to the victim, maintain community safety and rehabilitate the offender. This is the established position at common law in Australia, held by the High Court in Markarian v The Queen (2005), that the correct approach to sentencing is one that weighs all of the circumstances of the offence and the offender to reach an appropriate penalty. Justice McHugh further noted that a sentence can only be the product of human judgement, and sociological variables should rightly be considered. ${ }^{75}$

\section{Genuine Participation}

In reality, it may be difficult to ensure that an offender's participation in restorative justice processes is a genuine attempt to address underlying causes of criminal behaviour. A major criticism of restorative justice is that it is a 'soft option' that is

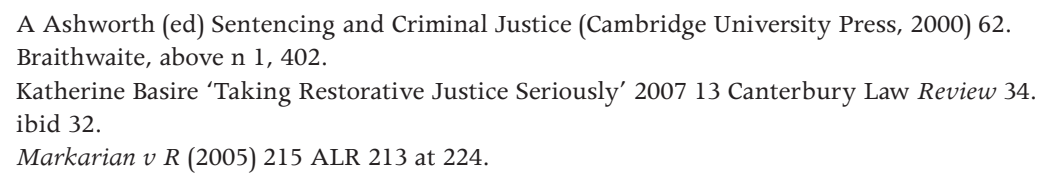


unlikely to be relevant to repeat offenders. ${ }^{76}$ It is not unlikely that offenders may elect to participate in restorative justice conferences with the sole motivation of achieving a reduced sentence. Whilst this is a concern, studies have indicated that restorative justice processes can be beneficial and have a meaningful impact on offenders regardless of their initial motivation for participation. ${ }^{77}$

\section{Conclusion}

Whilst restorative justice has drawbacks, and is unlikely to deliver the 'miraculous' outcomes some commentators claim it will, ${ }^{78}$ restorative justice has the potential to provide real benefits to all those involved in the criminal justice system. Simply locating and punishing antisocial behaviour, as the current criminal justice system tends to do, does not address the root causes of criminal conduct. Statistics have proven beyond doubt that the current system is particularly detrimental to Indigenous communities and, in failing to rehabilitate offenders, is perpetuating the social exclusion suffered by Indigenous offenders. Restorative justice allows the court system to move away from restrictive notions of crime and punishment, and better connect with the communities they serve by meeting the requirement of Bungy $v$ The Queen ${ }^{79}$ to consider the severe disadvantage suffered by Indigenous offenders.

This essay agrees that 'there can be no justice in a world without connectedness and empathy' ${ }^{80}$ It is hoped that the integration of restorative justice within South Australia's criminal justice system may achieve a system of justice that is both empathetic to the offender and addresses the severe historical disadvantage suffered by Australia's Indigenous community.

\section{Bibliography}

\section{Books}

Ashworth, A, (ed.), Sentencing and Criminal Justice (Cambridge University Press, 2000).

'Is Restorative Justice the Way Forward for Criminal Justice?', in E McLauglin et al. (eds), Restorative Justice - Critical Issues (SAGE Publications, 2003).

76 Hinchey, above n 50, 36

77 Basire, above n 74, 43.

78 See, for example, Braithwaite, above n 36.

79 [2013] HCA 37

80 Braithwaite, above $\mathrm{n} \mathrm{1,} 402$. 
The ANU Undergraduate Research Journal

Braithwaite, J, 'Restorative Justice and a Better Future', in E McLauglin et al. (eds), Restorative Justice — Critical Issues (SAGE Publications, 2003).

Coyle, A, The Prisons We Deserve (Harper Collins Publishers London, 1994).

Cunneen, C, Conflict, Politics and Crime: Aboriginal Communities and the Police (Allen \& Unwin, 2001).

Foucault, M, Discipline and Punish (Penguin Group London, 1977).

Garland, D, Punishment in Modern Society (Clarendon Press Oxford, 1990).

Marshall, T, Restorative Justice: An Overview (Home Office, Research and Statistics Directorate, 1999).

Maltz, MD, Recidivism (Academic Press, Inc., 1984).

Ober, C, et al., 'Debriefing in Different Cultural Frameworks: Responding to Acute Trauma in Australian Aboriginal Contexts', in B Raphael and JP Wilson (eds), Psychological Debriefing: Theory, Practice and Evidence (Cambridge University Press, 2000).

Winick, B and Wexler, D (eds), Judging in a Therapeutic Key (Carolina Press, 2003).

\section{Case Law}

Bugmy v The Queen [2013] HCA 37

Fernando (1992) 76 A Crim R 58

Kennedy $v$ The Queen [2010] NSWCCA 260

Markarian $v R$ (2005) 215 ALR 213

\section{Discussion Papers}

Allard, T, 'Understanding and Preventing Indigenous Offending', Brief 9 (Indigenous Justice Clearinghouse, 2010).

New Zealand Law Commission, Sentencing Guidelines and Parole Reforms, Discussion Paper 94 (2006).

Walker J and Salloom, S, 'Australian Prisoners 1992', Research Discussion Paper (Australian Institute of Criminology, 1993). 


\section{Government Documents}

ACT Justice and Community Safety, Annual Report 2012-2013 (2013).

Australian Bureau of Statistics (ABS), 'Experimental Estimates of Aboriginal and Torres Strait Islander Australians', Release no. 3238.0.55.001, June (2006).

Department of Human Services, Recidivism among Victorian Juvenile Justice Clients 1997-2001 (Government of Victoria, 2001).

Payne, J, Recidivism in Australia: Findings and Future Research, Research and Public Policy Series 80 (Australian Institute of Criminology, 2007).

Australian Government Productivity Commission, Report on Government Services, 31 January (2006).

\section{Journal Articles}

Allard, T, et al., 'Police Diversion of Young Offenders and Indigenous Overrepresentation', Trends \& Issues in Crime and Criminal Justice, 390 (2010): 1-6.

Basire, K, 'Taking Restorative Justice Seriously', Canterbury Law Review, 13 (2007): 31 .

Beven, J, et al., 'Restoration or Renovation? Evaluating Restorative Justice Outcomes in Psychiatry', Psychology and the Law, 12(1) (2005): 194-96.

Braithwaite, J, 'Setting Standards for Restorative Justice', British Journal of Criminology, 42 (2002): 563-77.

'Doing Justice Intelligently in Civil Society', Journal of Social Issues, 62 (2006): 393-409.

Goulding, D et al, 'Restorative Prisons: Towards Radical Prison Reform', Current Issues in Criminal Justice, 20 (2008): 231-42.

Hinchey, J, 'Restorative Justice in the Australian Capital Territory from Apprehension to Parole', Precedent, 72 (2006): 36-38.

Llewellyn, J, 'Dealing with the Legacy of Native Residential School Abuse in Canada: Litigation, ADR and Restorative Justice', Toronto Law Journal, 52 (2002): 253-300.

Marchetti E, and Daly, K, 'Indigenous Sentencing Courts: Towards a Theoretical and Jurisprudential Model’, Sydney Law Review, 29 (2007): 415-43. 
The ANU Undergraduate Research Journal

Marshall, T, 'The Evolution of Restorative Justice in Britain', European Journal of Criminal Policy and Research, 4(4) (1996): 21-43.

Richards, K, 'Police-referred Restorative Justice for Juveniles in Australia', Trends \& Issues in Crime and Criminal Justice, 398 (2010): 1-8.

Snowball, L, 'Diversion of Indigenous Juvenile Offenders', Trends \& Issues in Crime and Criminal Justice, 355 (2008): 1-6.

Steels, B, et al., 'When it's a Question of Social Health and Well-being, the Answer is not Prison', Indigenous Law Bulletin, (2009): 7.

\section{Legislation}

Crimes (Restorative Justice) Act2004 (ACT)

Criminal Law (Sentencing) Act 1988 (SA)

Explanatory Statement, Crimes (Restorative Justice) Bill 2004 (ACT)

Young Offenders Act 1993 (SA)

\section{Online Resources}

Department of Corrections, Overrepresentation of Maori in the Criminal Justice System: An Explanatory Report (2007), <http://www.corrections.govt.nz/_ data/assets/pdf_file/0004/285286/Over-representation-of-Maori-in-thecriminal-justice-system.pdf $>$.

Department of Justice, Evaluating the Neighbourhood Justice Centre in Yarra 2007-2009, Neighbourhood Justice Centre (Victorian Government 2010), $<$ http://www.neighbourhoodjustice.vic.gov.au $>$.

Harris, M, 'A Sentencing Conversation': Evaluation of the Koori Courts Pilot Program October 2002 - October 2004, Indigenous Justice Clearinghouse (2006), <http://indigenousjustice.gov.au/db/publications/272393.html>.

Laycock, D, Restorative Justice: Offering Benefits to Victims, Offenders and Communities, Centre for Restorative Justice (2010), <www.lawsocietysa.asn.au>.

\section{United Nations Publications}

ECOSOC Resolution 2002/12, Basic Principles on the Use of Restorative Justice Programmes in Criminal Matters (United Nations Publication). 


\section{Other}

Australian Law Reform Commission, Family Violence: Improving Legal Frameworks: Consultation Paper (ALRC CPS 1, April 2010).

Australian Institute of Health and Welfare, 'Juvenile Justice in Australia 200809', Juvenile Justice Series 7 (2011).

National Drug and Alcohol Committee, 'An Economic Analysis for Aboriginal and Torres Strait Islander Offenders: Prison vs Residential Treatment (Australian National Council on Drugs, August 2012). 
This text taken from The ANU Undergraduate Research Journal Volume Five 2013, published 2014 by ANU Press, The Australian National University, Canberra, Australia. 